\title{
Gatekeepers of the academic world: a recipe for good peer review
}

This article was published in the following Dove Press journal:

Advances in Medical Education and Practice

16 April 2015

Number of times this article has been viewed

\section{Aman Chowdhry \\ Department of Oral Pathology and Microbiology, Faculty of Dentistry, Jamia Millia Islamia, New Delhi, India}

Correspondence:Aman Chowdhry Department of Oral Pathology and Microbiology, Faculty of Dentistry, Jamia Millia Islamia, Maulana Mohammad Ali Johar Marg, New Delhi -I 1 0025, India Email achowdhry@jmi.ac.in

\section{Dear editor}

The peer review system relies on assessment of ingenious work by other people in the same domain in order to preserve or improve the quality and creativity of the work. ${ }^{1}$ Discussion and suggestions on improving the reliability of the process are made in this letter.

Peer review is like a gatekeeper in the academic world, and the methods for putting peer review into practice vary across journals and disciplines. The theory behind this system is that a larger and more diverse group of people will usually find more flaws in a work and will be able to make a more unbiased assessment of it than just the person or group who created the work. The strength and weaknesses of the peer review process have been discussed by Sollenberger in a review article. ${ }^{2}$

Peer review utilizes self-governance and the anonymity of the reviewers (referees) so as to discourage cronyism (ie, bias shown to family and friends) and obtain an unbiased report. The reviewers are not selected from amongst the close colleagues/ relatives/friends of the author.

The procedure of peer review is shown in Figure 1. Specialists in a given field judge the professional performance, creativity, or quality of scientific work produced by others in their field or area of competence. In single-blind review, the reviewer identity is hidden to encourage unbiased comments, while in double-blind review, the author's identity is masked from reviewers to shield against forms of social bias. Further, an "open peer" review journal may employ a "third" party, ie, someone who is neither affiliated directly with the reviewing entity nor associated with author being reviewed.

There can also be a system of postpublication open-review comments, normally mediated by the editor, that can be posted by readers and reviewers after the article has been published.

The scientific community is in search of ways to make peer review more efficient and effective. It is essential to maintain standards whilst also reducing the load on the reviewers (who are doing honorary work mostly). The process of peer review has evolved away from hard copy to a fully integrated online process, and all major journals usually accept online submissions. Thus peer review has become quicker and with a far lower administrative burden. But there is still plenty of room for improvement within the current peer review process. 


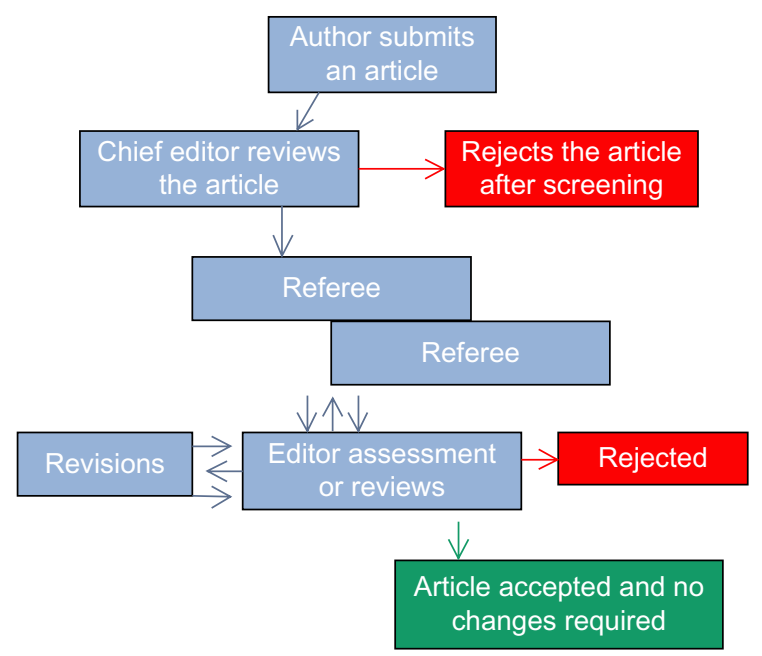

Figure I Procedure of peer review.

Editors are made, not born, and good team work along with technological support can help them do a better job. ${ }^{3}$ Thus reviewers and editors should be trained to adapt with the evolution in scientific publishing, and be aware that all digital pictures should mandatorily have attached metadata and embossed watermark. ${ }^{4}$

As recommended by Jolly, ${ }^{5}$ in addition, each paper can be allocated a "guardian", who is a member of the editorial board particularly accountable for ensuring the satisfactoriness of the peer review process and providing an extra viewpoint regarding the quality of the paper. Papers should only be accepted for publication after authors have aptly addressed the queries raised by the authority (referees/guardians/editor/ editorial board). Thus, in addition to peer review, multiplepoint quality checks in the review process are implemented by the editor and editorial board.

Another recommendation is adaptation of appropriate ethical policies, regulation, and best practice. Authors, reviewers, and editors will be required to read and adhere to these policies, which reflect the high standards we expect in peer review. A number of organizations (such as the International Committee of Medical Journal Editors and Committee on Publication Ethics) describe these policies for the peer review process.

\section{Disclosure}

The author reports no conflicts of interest in this communication.

\section{References}

1. Harris CD, Bratzler DW. Evaluating quality of care: The role of peer review. J Okla State Med Assoc. 2013;106(7):279, 281-279, 284.

2. Sollenberger JF. Editorial peer review: Its strengths and weaknesses. J Med Libr Assoc. 2002;90(1):115.

3. Sivapathasundharam B. Scientific writing: The Indian scenario. Indian J Dent Res. 2008;19(2):87.

4. Chowdhry A, Sircar K, Popli DB, Tandon A. Image manipulation: Fraudulence in digital dental records: Study and review. J Forensic Dent Sci. 2014;6(1):31-35.

5. Jolly PD. Re: Journal Standards - Editor's reply. $N$ Z Vet J. 2003; 51(4):199.

\section{Publish your work in this journal}

Advances in Medical Education and Practice is an international, peerreviewed, open access journal that aims to present and publish research on Medical Education covering medical, dental, nursing and allied health care professional education. The journal covers undergraduate education, postgraduate training and continuing medical education including emerging trends and innovative models linking education, research, and health care services. The manuscript management system is completely online and includes a very quick and fair peer-review system. Visit http://www.dovepress.com/testimonials.php to read real quotes from published authors. 